\title{
Evaluation of Food Safety of Commercial Baby Foods according to Legal Regulations
}

\author{
Iş11 Var, Sibel Özçakmak, Ali Tekin, Seda Yılmaz, Behzad Heshmati, \\ Okşan Uçkun, and Asya Çetinkaya
}

\section{ABSTRACT}

It has recently been recognized that some commercial infant formulae have, due to spoilage and pathogen microorganisms, which are detected risks to health, been recalled and reported in the Rapid Alert System for Food and Feed on notification lists. The risk of microbial contamination from the environment or from the addition of ingredients to cereal-based follow-on formulae (FOF) and powdered infant foods (PIF) products could occur under poor hygienic conditions. This project was designed to evaluate the associated risks of Cronobacter sakazakii, Salmonella, Total Coliform, E. coli, E. coli O157:H7, Staphylococcus aureus, Listeria monocytogenes, Bacillus cereus and Ochratoxin-A in PIF, FOF and rice flour products marketed in Turkey. Seventy-four baby formulae and thirteen rice flour trademarks obtained in 2018 randomly from different markets in Samsun, Kars, and Adana in Turkey. Salmonella, C. sakazakii, Coliform, $S$. aureus, $L$. monocytogenes and Bacillus cereus were analyzed using the ISO 6579:2002, ISO/TS 22964:2006, MPN, FDA (2001), FDA (1998) and FDA (2012) methods, respectively. $C$. sakazakii was isolated from 7/74 FOF products and 4/13 rice flour products, yielding $12.64 \%$ prevalence. Salmonella, $S$. aureus and $L$. monocytogenes were not detected in any of the samples. The FOF products, including cereals of different origins and one rice flour sample $\mathbf{( 7 . 6 9 \% )}$, were found to be contaminated with $B$. cereus $(6.76 \%)$ and $B$. subtilis $(5.41 \%)$. OTA values were found to be above the legal limits in $4.05 \%(3 / 74)$ FOF products. These results suggest that routine quality controls and hazard and risk analysis for infant foods have to be much more rigorous in terms of the potential risk of microbiological contamination.

Keywords: Cereal-based follow-on formulae (FOF), foodborne pathogens, Ochratoxin-A, food safety.

\section{INTRODUCTION}

The World Health Organization (WHO) and the United Nations Children's Fund (UNICEF) suggest that complementary foods can be started at six months [1]. Powdered infant foods (PIF) and cereal-based follow-on formulae (FOF) include many nutrients, such as proteins, minerals, fats, vitamins and other ingredients. Therefore, all over the world, mothers use infant formulae and infant supplements to meet the requirements for normal growth and development [2]. Cereal-based baby foods are an important component of infant nutrition. Babies and young children have very weak immune systems, so food safety in baby food is very important, and it must be evaluated for
Submitted : September 14, 2021

Published : October 06, 2021

ISSN: 2684-1827

DOI: $10.24018 /$ ejfood.2021.3.5.373

Işıl Var

Department of Food Engineering, Cukurova University, Adana, Turkey.

(e-mail: ivar@cu.edu.tr)

Sibel Özçakmak*

Directorate of Provincial Agriculture and Foresty, Samsun, Turkey.

(e-mail: sibel.ozcakmak@tarimorman.gov.tr) Ali Tekin

Department of Food Technology, Alata Horticultural Research Institute, Mersin, Turkey.

(e-mail: alitekin2006@gmail.com).

Seda Yılmaz

Adana Food Control Laboratory Directorate, Adana, Turkey.

(e-mail: sedasultan3349@gmail.com)

Behzad Heshmati

Department of Biotechnology, Institute of Natural and Applied Sciences, Cukurova University, Adana, Turkey.

(e-mail: behzadmicro@gmail.com)

Okşan Uçkun

Adana Food Control Laboratory Directorate, Republic of Turkey Ministry of Agriculture and Forestry, Adana, Turkey.

(e-mail: uckun_oksan@hotmail.com).

Asya Çetinkaya

Department of Food Engineering, Collage of Engineering and Architecture, Kafkas University, Kars, Turkey.

(e-mail: a_cetinkaya36@hotmail.com

*Corresponding Author

biological, chemical and physical contamination [3]. The mycotoxins could have greater health implications for infants due to their vulnerability [4]. Since consumption of OTA-contaminated baby foods could result in serious toxic effects, tolerable levels of OTA limits arranged carefully for cereals and cereal-based products [5].

To ensure optimum standards and prevent nutrient deficiencies in the products used in nutrition for infants and young children, the production stages and their release into the market have been determined according to the Codex Alimentarius Standard (CXS). The CXS 74-1981 Standard for Processed Cereal-Based Foods for Infants and Young Children was a re-evaluation of certain essential composition and quality factors, food additives, and labeling 
by the Codex Alimentarius on September 21, 2017 and October 29, 2019 [6]- [7]. In section five of CXS 074-1981, Rev. 1-2006, it has been stated that these products must comply with the microbiological criteria in the Establishment and Application of Microbiological Criteria (2073/2005/EC) [8]. which was implemented in parallel with European Union Commission Regulation (Law of Authorization: 5996, Official Gazette of Publication: 29.12.2011-28157) 2073/2005/EC on Microbiological Criteria for Foodstuffs in Turkey. According to law, Cronobacter sakazakii, Bacillus cereus, Staphylococcus aureus, Salmonella spp., Listeria monocytogenes, Clostridium perfringes, Enterobacteriaceae and E. coli O157:H7 [9]. must be absent in dried infant food and follow-on formulae, and for infants below six months of age, food and food enterprises have to obey these criteria.

Infections linked with $C$. sakazakii, total coliform bacteria, Salmonella spp., Coagulase Positive Staphylococcus, Esherichia coli, Bacillus spp. (B. cereus and B. subtilis), L. monocytogenes, and E. coli $\mathrm{O} 157: \mathrm{H} 7$ in follow-up formulas and small child supplementary foods have been increasing in many countries over recent decades [10]-[16].

Recalls due to bacterial contamination in baby food and formulae manufacturers were issued in 2017, 2018, 2019 and 2020 in different countries by government health authorities [17]. Powdered infant formula recalled worldwide is likely due to contamination with Cronobacter spp. and Salmonella. The first report on deadly infection due to Cronobacter in dried milk and powdered formula was issued in December 2011 in Missouri for products purchased at Wal-Mart. After one baby died and another became seriously ill from the same bacterial infection, these products removed from shelves. It is also, in September 2016, the FDA reported that one firm that produces powdered baby food was not found suitable in accordance with legal regulations, especially because the product was not tested for Cronobacter. In June 2016, in Michigan, USA, a baby less than one-month old died from meningitis and sepsis caused by Enterobacter sakazakii. A French firm in December 2017 recalled several of their baby formula products destined for markets including China, Greece, Pakistan and Peru after 26 infant cases were associated with Salmonella poisoning in France. In June 2018, the French firm withdrew the baby formula with powdered milk from 83 countries in terms of because of Salmonella (CFIA) [17][19]. The food recall in October 2019 by Canadian Foods Inspection Agency was reported which related to lactose milk-based powder infant formula contaminated with Cronobacter spp.

Although many studies have reported the presence of foodborne pathogens in PIF products, the food safety problems in these products have been continued. On the other hand it was also seen that few studies are available in terms of the prevalence of Bacillus spp, Staphylococcus aureus, E coli O157, Listeria monocytogenes, and OchratoxinA in cereal-based infant foods [20]-[10]. The objective of this study was to investigate whether the levels of C. sakazakii, Salmonella, Coliform, E. coli O157: H7, S. aureus, L. monocytogenes, B. cereus and OTA were below the statuary limit in powdered infant formulae, and rice flour product. Thus, it contributes to the literature by once again evaluating the condition of baby food and its raw materials. In this research, the presence of foodborne pathogens was detected using classical isolation methods, and OTA analysis was performed using the HPLC-FLD method.

\section{MATERIAL AND METHODS}

\section{A. Sample Collection}

For use as material, a total of 87 commercial samples were obtained in 2018 randomly from different markets in Samsun, Kars, and Adana in Turkey. The samples labeled were composed of 74 baby formulae $(\mathrm{PIF}=23, \mathrm{FOF}=51)$ and 13 rice flour products (DP1, DP2, DP3, MP1, MP2, MP3, K1, K1, K2, SP1, SP2, PM1, PP1). Information on the analyzed products is presented in Table 1 . The codes of AP, GP and HB were domestic $(n=45)$, while BG, AK and HP were imported $(n=29)$ baby food products.

TABLE I: THE CODES AND TYPES OF INFANT FORMULAE

\begin{tabular}{cc}
\multicolumn{2}{c}{ TABLE I: THE CODES AND TYPES OF INFANT FORMULAE } \\
\hline PIF & FOF \\
\hline AP1-AP13 & AP14-AP25 \\
HB1-HB6 & HB7-HB18 \\
BG4-BG5, BG9 & BG1-BG3, BG6-BG8, BG10-BG11 \\
GP1 & GP2 \\
& AK1-AK12 \\
& HP1-HP6 \\
\hline Total number of & Total number of \\
PIF samples $=23$ & FOF samples = 51 \\
\hline
\end{tabular}

The samples were sealed and kept in their own packages in the laboratory until analysis. Aseptic conditions during sample collection, transportation to the laboratory and preparation of sample homogenate were applied. Each sample was examined for $C$. sakazakii, Salmonella, Total Coliform, S. aureus, L. monocytogenes, B. cereus and OTA.

\section{B. Isolation and Determination of Cronobacter sakazakii}

Samples were tested for the presence of Cronobacter spp. (previously referred to as Enterobacter sakazakii) according to the standard procedures described in the ISO/TS 22964:2006 [21]. Samples of $25 \mathrm{~g}$ infant formulae and rice flour were weighed under aseptic conditions and added to $225 \mathrm{~mL}$ Buffered Peptone Water (BPW) for pre-enrichment. At the end of $18 \mathrm{~h}$ of incubation at $37{ }^{\circ} \mathrm{C}$, a $0.1 \mathrm{~mL}$ sample was taken and inoculated into the pre-enrichment medium (10 mL LST/Vancomycin Medium) before being incubated at $44{ }^{\circ} \mathrm{C}$ for $24 \mathrm{~h}$. After incubation, colonies changing from green to blue-green and between one and three $\mathrm{mm}$ on the agar were evaluated as suspicious colonies, and these were then inoculated on Tryptic Soy Agar. Biochemical verification tests were performed on the yellow colonies grown in Tryptic Soy Agar.

\section{Isolation and Determination of Staphylococcus aureus}

The determination of $S$. aureus in baby foods was conducted using the method offered by the Food and Drug Administration [22]. A $10 \mathrm{~g}$ sample was homogenized with $90 \mathrm{~mL}$ sterile peptone water. After the serial dilutions were performed, Baird-Parker agar medium was used for the isolation of $S$. aureus. For this purpose, instead of standard petri dishes, a $1 \mathrm{~mL}$ sample was put directly into $14 \mathrm{~cm}$ diameter petri dishes. A coagulase test was performed to 
verify that the isolates that were blackish in color and formed a clear zone around it after $48 \mathrm{~h}$ of incubation at $37^{\circ} \mathrm{C}$ were $S$. aureus. For this purpose, clear zoned black colonies on Baird-Parker agar medium were inoculated in Brain-Heart Broth medium and incubated at $37^{\circ} \mathrm{C}$ for $24 \mathrm{~h}$, the coagulase test was then applied to the culture.

\section{Isolation and Determination of Salmonella spp.}

Salmonella spp. isolation was carried out with the classical isolation method, i.e., the ISO 6579 method [23]. An aseptically weighed $25 \mathrm{~g}$ sample was transferred into $225 \mathrm{~mL}$ of buffered peptone water and then homogenized. The mixture was incubated at $37^{\circ} \mathrm{C}$ for $16-20 \mathrm{~h}$. At the end of the incubation period, a $0.1 \mathrm{~mL}$ mixture was transferred into $10 \mathrm{~mL}$ of Rappaport-Vassiliadis Broth (RVS) incubated at $42{ }^{\circ} \mathrm{C}$ for $7 \mathrm{~h}$. $1 \mathrm{~mL}$ of the same culture was taken and transferred to tubes containing $9 \mathrm{~mL}$ of Selenite-Cystine Medium and incubated at $37^{\circ} \mathrm{C}$ for $7 \mathrm{~h}$ [24]. One loopful of enrichment culture from two different mediums was inoculated on both Xylose Lysine Desoxycholate (XLD) agar and Hektoen Enteric Agar and then incubated at $37{ }^{\circ} \mathrm{C}$ for $24 \mathrm{~h}$. Central black colonies or all-black colonies growing on XLD agar medium and central black colonies or green to bluish-green colonies growing on Hektoen Enteric agar medium were accepted as suspicious Salmonella colonies. For further identification, the suspicious colonies were inoculated in nutrient agar (NA) and incubated at $37^{\circ} \mathrm{C}$ for $24 \pm 2 \mathrm{~h}$. Suspect colonies isolated in pure culture were inoculated on Triple Sugar Iron agar (TSI), Lysine Iron Agar and Urea Broth (UB) media for biochemical confirmation [25]- [26].

\section{E. Isolation and Determination of Coliform and E. coli O157:H7}

Coliform bacteria counts were performed according to the most probable number (MPN) method using a Fluorocult Lauryl Sulfate Broth (Merck) medium [27], [28]. After preparing and diluting the samples, one milliliter of each sample was inoculated into fermentation tubes containing Fluorocult ${ }^{\circledR}$ Lauryl Sulfate Broth and then incubated at $37^{\circ} \mathrm{C}$ for $24-48 \mathrm{~h}$. After the incubation period, tubes that developed turbidity and formed gas were evaluated as coliform bacteria. A fluorescence test with UV light and an indole test with Kovac's Indol reagent were applied to these tubes. Fluorescence and indole positive tubes were evaluated as Escherichia coli Type I, while fluorescence negative and indole positive tubes were evaluated as $E$. coli O157: H7. The results were evaluated according to the MPN table [27]. In addition, confirmation of E. coli O157:H7 was carried out. Since E. coli O157:H7 that cannot use sorbitol at the end of the incubation form colorlessly in Fluorocult $E$. coli O157:H7 Agar [29] confirmation was also performed for $E$. coli $\mathrm{O} 157: \mathrm{H7}$.

\section{F. Isolation and Determination of Listeria spp.}

Isolation of Listeria spp. in baby formulae was carried out according to the method recommended by the FDA [30]. For this purpose, $25 \mathrm{~g}$ sample put in Buffered Listeria Enrichment Broth (BLEB) medium and pre-enrichment was performed. It was incubated at $30{ }^{\circ} \mathrm{C}$ for $48 \mathrm{~h}$. Four hours after the start of incubation, a selective additive $(0.2 \mathrm{mg} / \mathrm{L}$ acriflavine, $0.8 \mathrm{mg} / \mathrm{L}$ nalidixic acid for each tube) was added, and the incubation was completed in $48 \mathrm{~h}$. At the 24th and 48th $\mathrm{h}$ of incubation, a loopful of culture was streaked to the selective solid medium PALCAM Agar and left to incubate at $37^{\circ} \mathrm{C}$ for $48 \mathrm{~h}$. Suspect colonies with a diameter of 1.5-2 mm-olive green-gray and black zonesgrowing on selective solid media were evaluated [31]. After performing some biochemical tests (gram staining, catalase and oxidase) to identify suspicious colonies, they were inoculated on a TSA-YE (Tryptone Soy Agar-Yeast Extract) medium for purification. After $24 \mathrm{~h}$ of incubation, the colonies were identified on the basis of species using the Vitek 2 automated system.

\section{G. Isolation and Determination of Bacillus cereus}

$B$. cereus isolation from the examined food samples was performed using the "Bacillus cereus Isolation from Food" section published in section 14 of the BAM (Bacteriological Analytical Manual) according to January 2012 data on the official website of the FDA [32]. Samples (10 g) were placed in stomacher bags containing $90 \mathrm{~mL}$ of Peptone Water (Merck) and then homogenized. $1 \mathrm{~mL}$ of the enrichment culture was streak-plated on Mannitol Egg Yolk Polymyxin agar incubated at $30^{\circ} \mathrm{C}$ for $16 \mathrm{~h}$. At the end of the incubation, typical pink (reddish) colonies with a precipitation zone were evaluated as $B$. cereus suspicious colonies and, with the other different colonies, were isolated and subjected to further identification tests [32]-[33].

\section{H. Detection of Ochratoxin A (OTA)}

\section{1) Sample Preparation}

The analysis was carried out according to the official AOAC (2014) [34]. method. A $25 \mathrm{~g}$ sample and $125 \mathrm{~mL}$ acetonitrile + water $(70: 30, \mathrm{v} / \mathrm{v})$ were placed in a blender bowl and blended at high speed for $2 \mathrm{~min}$ in a Waring blender. The mix was filtered through Whatman No. 1 filter paper and the filtrate collected in a conical flask. $10 \mathrm{~mL}$ of this filtrate was diluted with approximately $40 \mathrm{~mL} \mathrm{PBS}$ and passed through a microfiber glass filter.

\section{2) Affinity Chromatography}

$25 \mathrm{~mL}$ of filtrate was passed by OchraTest immunoaffinity column. The column was washed twice with $10 \mathrm{~mL}$ of ultra-pure water, and air was passed through to dry it. To get the OTA from the column to the vial, $1 \mathrm{~mL}$ of methanol+acetic acid $(98: 2, \mathrm{v} / \mathrm{v})$ and $1 \mathrm{~mL}$ of water were passed through the column and injected into the HPLC-FLD (Agilent, USA) as $100 \mu \mathrm{L}$.

\section{3) HPLC Analysis of OTA}

HPLC-FLD was used to determine the OTA content of the standards and samples. The HPLC system used for this study consisted of a pump (1200 Series, Agilent, USA), a column oven (1200 Series, Agilent, USA) and a fluorescence detector (1200 Series, Agilent, USA). A reverse-phase C18 column $(250 \times 4.6 \mathrm{~mm}, 5 \mu \mathrm{m}$, Advanced Chromatography Technologies, Scotland) was used. The isocratic mobile phase was a solution of acetonitrile: ultrapure water: acetic acid: (48:51:1, v/v/v). Fluorescence detection was performed at an excitation wavelength of 333 $\mathrm{nm}$ and an emission wavelength of $470 \mathrm{~nm}$. 


\section{4) Calibration Curve}

For Ochratoxin A, the calibration curve was prepared by using six different working standard solutions. Six different concentrations of OTA $-0.25,0.50,1,2,4$ and $8 \mu \mathrm{g} / \mathrm{kg}$ were used in the calibration. The calibration curve was created to check the linearity $(\mathrm{r} 2=0.999)$ of the pilot prior to analysis and used to quantify Ochratoxin A. The Limits of Detection (LOD) were found as $0.1 \mu \mathrm{g} / \mathrm{kg}$ for Ochratoxin A. The retention time with a $1 \mathrm{~mL} / \mathrm{min}$ flow rate was 12.40 min, and the total run time was $17 \mathrm{~min}$. The spiked sample was injected 10 times. The total recovery of Ochratoxin A was $87 \%$.

\section{RESULT AND DISCUSSION}

\section{A. The prevalence of Cronobacter sakazakii}

A total of 87 powdered infant formulae (PIF) and cerealbased follow-on formulae (FOF) with six different trademarks and rice flour products with seven different trademarks were analyzed for the presence of $C$. sakazakii. A total of five $C$. sakazakii isolates from 51 FOF, two isolates from 23 PIF and four isolates from 13 rice flour products were obtained. $C$. sakazakii colonies were confirmed in 7 of 51 cereal-based FOF products (AP6, AP9, AP14, AP20, AP22, AP24 and HB3) and in 4 of 13 rice flour samples $(30.77 \%)$. The prevalence of $C$. sakazakii was found to be $12.64 \%$ (11 out of 87 ). C. sakazakii was detected in 51 FOF samples, six of which were domestic $(22.22 \%, 6 / 27)$ and one imported $(2.13 \%, 1 / 47)$.

Seven isolates that had a positive reaction to indole but were not identified as $C$. sakazakii were found (Table II). Although there were only Escherichia coli showed indolepositive feature among the microorganisms found in the competitive flora of $C$. sakazakii in Tryptic Soy Agar that it could not be evaluated as $E$. coli because other biochemical features of $E$. coli were incompatible. At the same time, these seven isolates were evaluated for other species of Cronobacter, and all other biochemical properties were found to be parallel to the biochemical properties of Cronobacter, except for the positive results for Indole. When we looked at the information in the literature, it was concluded that these colonies could be the species $C$. muytjensii, $C$. dublinensis subsp. dublinensis, or $C$. dublinensis subsp. lactaridi.

Using the ISO/TS 22964:2006 method [21], 55\% of the isolates obtained from 20 samples that yielded suspicious $C$. sakazakii colonies were identified as C. sakazakii and $10 \%$ as Enterobacter cloacae, while 35 percent of the isolates were thought to be Proteus mirabilis, Escherichia coli or Enterococcus faecalis. [35] investigated the presence of $C$. sakazakii in 160 samples, including 60 milk powder and 50 white cheese samples, using the ISO/TS 22964:2006 method. They found $C$. sakazakii in $5 \%$ of milk powders and in $3 \%$ of white cheeses. [20] found C. sakazakii in two of the infant milk powders and five of the dry infant formulas in their study in which they investigated 82 infant milk powders and 49 dry infant formulas using the DrugganForsythe-Iversen agar (DFI agar) developed by them.

In our study, it was found that the PIF and FOF samples $(9.46 \%, 7 / 74)$ were contaminated with $C$. sakazakii. Similar to our data, reports by some researchers [36]-[37]-[38] found a contamination risk of E. cloacea, E. agglomerans, $C$. sakazakii and $C$. muytjensii isolates in baby foods. Interestingly, the prevalence of $C$. sakazakii was highest in cereal-based (mostly rice flour, 4/7) FOF products. Infants, who are more susceptible to infections caused by $C$. sakazakii than adults, are in a high risk group. These results once again demonstrate that cereal-based infant formulae are not adequately safe as food. Therefore, it has been seen that there is still a need to advance the food safety level of infant formulae products.

The test for Cronobacter spp., which threatens the health of the infant and young child age group, is mandatory for all countries to provide a protective effect against danger. Moreover, when it comes to infant formulas, it is believed that the same food safety standards must be followed for all countries. It is known that infants (up to 12 months, especially the first two months) and advanced age groups (up to two years of age) are significantly affected by Cronobacter infection, and severe symptoms, such as Cronobacter-related meningitis and high fever, have been observed. According to the Codex Alimantarius (EC/2072/2005) [8], legal limitations exist on C. sakazakii for infant and follow-up formulas only. However, our research findings showed that the prevalence of $C$. sakazakii for FOF was $13.72 \%$ and for PIF products was $8.69 \%$ in grain-based processed supplementary foods. Therefore, it can be argued that the search for $C$. sakazakii should be a criteria of food safety not only in follow-up formulas but also in complementary foods.

TABLE II: BIOCHEMICAL PROPERTIES OF MICROORGANISMS FOUND IN THE COMPETITIVE FLORA OF

\begin{tabular}{cccccccccc}
\hline \multicolumn{7}{c}{ C. SAKAZAKII THAT CAN GROW ON TRYPTIC SOY AGAR } \\
\hline E.cloacea & - & - & - & + & + & + & - & + \\
Pram (+/-) & Indole & MR & VP & Citrat. & Catalase & Oxidase & Flagella \\
E. coli & - & - & - & & & + & - & + \\
E. faecalis & - & + & + & - & - & + & - & + \\
\hline
\end{tabular}

B. The prevalence of $S$. aureus, Salmonella spp. and L. monocytogenes

S. aureus, Salmonella spp. and L. monocytogenes are the most common foodborne pathogenic bacteria worldwide. Since the contamination of other foodborne pathogens in infant formulae has been studied less than $C$. sakazakii [21]. There is little information on whether infant formulae can be a source of $S$. aureus, Salmonella spp. and $L$ monocytogenes infection in infants [40]-[42], [10].

Consequently, the possibility of $S$. aureus, Salmonella spp. and L. monocytogenes contamination in PIF and FOF products was evaluated in this study. It is gratifying that not all cereal-based follow-on formulae, potent infant formulae and rice flour samples were found to be contaminated by these food-borne pathogens. PIF products could be 
contaminated with various bacteria, including certain pathogens, under insufficient hygienic conditions. S. aureus, a significant cause of foodborne disease, is commonly isolated in foods of animal origin [40], [12]. Neonatal infections by coagulase-negative staphylococci and $S$. aureus have been reported by [43], the FAO and WHO [44], [40], and [10]. Staphylococci produce enterotoxins, which are a common cause of bacterial food poisoning. The presence of $S$. aureus strains in infant foods leads to microbiological hazards to infant health.

Although foodborne Listeriosis, caused by the bacterium L. monocytogenes in category C (less likely for infant foods), has not been identified in PIF products, it should be taken into account, and Codex limits should be considered Food Safety Criteria [8], [44]. The meeting of the 37th Session of the Codex Committee on Food Hygiene concluded that the risk of E. sakazakii and Salmonella in PIF products could be eliminated with a food safety management system [40]. Good hygiene practices have vital importance in effective food safety management, as does monitoring all food safety hazards. Contamination and/or recontamination in the food production lines for infants and young children could perpetuate fatal infections [20], [45], [46]. EC Regulation 2073/2005/EC for PIF products has been applied in Turkey. Bacillus cereus, C. sakazakii, Salmonella and L. monocytogenes for infant formulae and follow-on formulae (including dietary foodstuffs for special medical purposes) and $B$. cereus, Enterobacteriaceae, Salmonella and L. monocytogenes in food supplements for infants and children (including dietary foodstuffs for special medical purposes) are accepted as Food Safety Criteria by Commission Regulation (EC) No 2073/2005 [8]. These results highlight that the risk of contamination by the other most common foodborne pathogens should be taken into account in international legal microbiological criteria.

\section{The Prevalence of Coliform and E.coli $\mathrm{O} 157: \mathrm{H} 7$}

The presence of coliform bacteria in the samples which were absent of fecal coliforms suggests that in rice flour production conditions was available that it is mostly plantderived coliform. That show it may mean that there was a problem with good hygiene practices and crosscontamination in the rice flour mill [47]-[49].

TABLE III: PREVALENCE OF COLIFORMS IN FOF AND RICE FLOUR

\begin{tabular}{ccc}
\multicolumn{3}{c}{ PRODUCTS $(\mathrm{N}=87)$} \\
\hline Sample type & $\begin{array}{c}\text { Code of the } \\
\text { sample }\end{array}$ & $\begin{array}{c}\text { Coliform } \\
(\mathrm{MPN} / \mathrm{g})\end{array}$ \\
\hline Cereal-based follow-on & AP20 & 210 \\
formulae & AP21 & 230 \\
(FOF) & AP22 & 240 \\
& K1 & 9.2 \\
Rice flour & KP1 & 28 \\
& MP1 & $>1100$ \\
\hline
\end{tabular}

There have been many reports about the presence of the Enterobacteriaceae family in PIF and FOF products up to now [15], [20], [41], [50]-[55]. Thus, further official food controls on infant food manufacturers may be needed in terms of food safety criteria. In addition, it should be ensured that good manufacturing practice principles and risk assessments are carried out throughout the production stages in factories [56].

If milk powder and cereal-based ingredients, which are widely used in infant formulae formulation components, are of low microbiological quality and obtained under insufficient hygienic conditions, the final product will certainly become contaminated. Moreover, foodborne pathogen contamination of infant foods can occur during production or mixing preparation [57], [55]. Because babies and children are extremely susceptible to epidemic diseases, the presence of intestinal bacteria in the foods they consume can lead to serious health problems [2]. Therefore, food managers must obey food laws specifying the general principles and requirements of food safety. Although it is stated on the label information that production is made in accordance with Food Safety Management Systems, it has been seen that the data obtained in this study contradict the microbiological quality of both imported and domestic commercial baby and small child supplementary foods. Therefore, these enterprises need to be more strictly controlled. Furthermore, the number of microbiological analyses undertaken on baby foods and small children's supplementary food products within the first year should be increased by the relevant authorities.

\section{The Prevalence of Bacillus spp.}

Two important pathogens that form spores and show resistance to the heat process are B. cereus and B. subtilis were observed some of the studied samples. Although they were not detected in a total of 23 PIF products, in 7 out of 51 FOF (13.73\%) and 1 out of 13 rice flour samples (7.69\%), they were found to be positive (Table IV).

TABLE IV: The PREVALENCE OF B. CEREUS AND B. SUBTILIS IN FOF AND

\begin{tabular}{cccc}
\multicolumn{4}{c}{ RICE FlOUR SAMPLE (N=87) } \\
\hline \multirow{2}{*}{ Sample type } & $\begin{array}{l}\text { Code of } \\
\text { the sample }\end{array}$ & B. cereus & B. subtilis \\
& HB1 & + & - \\
Cereal-based & HB6 & + & - \\
follow-on & HB12 & - & + \\
formulae & HB13 & + & + \\
(FOF) & HB14 & + & + \\
& HB16 & + & - \\
Rice flour & HP4 & + & + \\
\hline
\end{tabular}

Similarly, a study on the microbiological quality of baby food by [58] found that 36 samples from different brands were contaminated with Bacillus cereus. A researcher [59] reported that $3.3 \%$ of the samples they tested were contaminated with $B$. cereus, while another [50] found that over $64.3 \%$ of the tested samples contained high counts of Bacillus spp. (2 $\log 10 \mathrm{CFU} / \mathrm{g})$. A study [61] reported that Bacillus cereus was isolated from baby food in only two $(1.25 \%)$ of 160 samples, and the number of Bacillus cereus was between $2 \times 10^{1}$ and $4 \times 10^{1} \mathrm{cfu} / \mathrm{g}$. The prevalence of $B$. cereus in our study $(9.19 \%)$ was found higher than in [59] and [61] but lower than in [60].

\section{E. The Detection of Ochratoxin-A (OTA)}

OTA, which causes endemic nephropathy and is classified as a possible human carcinogen (Group 2B), was also investigated in this study. The maximum level of OTA in infant formulae and follow-on formulae was $0.5 \mu \mathrm{g} / \mathrm{kg}$ according to European Commission No. 1881/2006, which set maximum levels for certain contaminants in foodstuffs [62], [63]. 
OTA contamination was detected in five cereal-based follow-on formulae $(9.8 \%)$, and the OTA levels in three of these samples exceeded the permission level. Three of the samples in both domestic and imported brands had levels of mycotoxin $\left(5.48,0.82\right.$ and $\left.0.75 \mu \mathrm{g} \mathrm{g}^{-1}\right)$ above the maximum level for certain contaminants in infant formulae and followon formulae currant products (Table 5). The frequency distribution of OTA was detected as $5.75 \%$ (5/87). Although there was no detection of OTA in PIF and rice flour products, the results yield very important ideas about the prevalence of OTA contamination in FOF product samples studied in this research in Turkey.

TABLE V: OCCURRENCE OF OCHRATOXIN-A IN CEREAL-BASED FOLLOW-

\begin{tabular}{cc}
\multicolumn{2}{c}{ ON FORMULAE } \\
\hline Sample & $\begin{array}{c}\text { Ochratoxin A, } \mu \mathrm{g} / \mathrm{kg} \\
\text { Mean } \pm \text { SD }\end{array}$ \\
\hline AP1, rice-based, (domestic) & $0.35 \pm 0.01$ \\
AP25, rice-based and banana, (domestic) & $0.82 \pm 0.05$ \\
AP16, milk with mixed vegetables, & $0.46 \pm 0.01$ \\
(domestic) & \\
AK9, milk + cereal-based with currant, & (imported) \\
AK11, milk + fruit, (imported) & $0.48 \pm 0.01$ \\
\hline
\end{tabular}

Reports by [64], [65] and [66] on mycotoxins in cerealbased infant foods show very low OTA concentrations found in these foods relative to our results. Cereal grains can be infected by mycotoxigenic fungi pre-harvest or postharvest [67]. The occurrence of mycotoxins in grains means that the toxicological hazard could come out in the last product [68]. Therefore, it is important to ensure food safety. Mycotoxins have attracted worldwide attention due to their capability of causing serious problems to human health, and cancer effects. The agents evaluated by the IARC Monographs programmer are classified into five groups (Group 1, 2A, 2B, 3 and 4) defined by the existing scientific evidence for their carcinogenicity. OTA is classified as a possible human carcinogen (Group 2B) by the International Agency for Research on Cancer (IARC) due to its nephrotoxic, immunotoxic, genotoxic and teratogenic effects [69]. According to the preparation instructions on the FOF sample labels, a baby takes in $25 \mathrm{~g}$ of formulae per portion. If a 6-month-old child with a body weight of $7.5 \mathrm{~kg}$ and infant formulae with the highest quantity of ochratoxin A found weekly $(5.48 \mu \mathrm{g} / \mathrm{kg})$ were considered, the maximum portion intake would be $0.966 \mu \mathrm{g}$ OTA per body weight $(\mathrm{kg})$. The provisional tolerable weekly intake (PTWI) is $0.1 \mu \mathrm{g} / \mathrm{kg}$ body weight for ochratoxin-A [70]. The total daily mycotoxin intake could be an important risk factor for infants and young children [66], [42].

In this study, OTA was found in three of the samples, and both domestic and imported brands had levels of mycotoxin (5.48, 0.82 and $0.75 \mu \mathrm{g} \mathrm{g}^{-1}$ ) above the maximum level for certain contaminants in infant formulae and follow-on formulae currant products (Table V). The occurrence of OTA in cereals and cereal-based foods has been reported in different countries at different concentrations. OTA content due to fungal spoilage of organisms, especially during the postharvest process in cereal-based products, could exceed the permitted European levels [71]. Cereal-based infant products are potential sources of mycotoxins. It has been observed that there is a limited amount of literature on mycotoxins in rice and the other cereal-based infant and follow-on formulae products. A few searches for the presence of mycotoxins such as deoxinivalenol, zearalenone and OTA in cereal-based infant formulations have been reported [65], [66], [20], [5]. If the rice used in the production of infant food is exposed to OTA contamination, it is likely to be present in the final product [68]. Moreover, it is necessary to ensure that microbiological evaluations comply with the legislation not only in the final product but also in the components included in the formulation. If food safety risk could be detected from the beginning of production to the end of the distribution stage, imported and exported infant foods could have fewer potential health risks.

\section{CONCLUSIONS}

The prevalence of pathogenic contamination ( $C$. sakazakii, coliform, which is a member of the Enterobacteriaceae family, Bacillus cereus and B. substilis) and the detection of OTA in milk-based and cereal-based infant food and rice flour was found at considerable levels. The results showed that powdered infant formulae, especially cereal-based ones, need more frequent formal food control. It is necessary that new microbiological criteria, such as mycotoxigenic fungi, yeast and mold, $B$ subtilis, etc. should be taken into account for food safety, while process hygiene criteria should be implemented for infant and follow-on formula.

In cereal-based formulations used in the nutrition of infants and young children, the microbial status of raw cereal materials (such as wheat, rice and corn) as well as milk, fruits and vegetables changes the microbiological quality of the final product [66]-[72]. Since honey may contain $C$. botulinum spores that cause infant botulism, it is recommended not to be given to infants up to 12 months of age [73]. In some imported/domestic additional foods sold commercially on the market, honey could be included as an ingredient. In this study, it was seen that $8.11 \%(6 / 74)$ of the products examined contained honey in their composition. According to international/national legislation, there are no criteria regarding the risk of $C$. botulinum among the microbiological criteria of processed grain/non-processed cereal-based complementary foods in infants (up to 12 months) and young children (12-36 months). Not only food business operators are required to ensure that infant foods meet the relevant microbiological criteria, but it should also be mandatory for all countries to use globally applicable legal limits for these imported and exported product groups. It has been shown that calling for the revision of legal criteria and limits in terms of food pathogens in cereal-based baby foods and supplementary foods for young children is mandatory in terms of protecting the health of infants and young children.

\section{ACKNOWLEDGEMENT}

This study was supported by Çukurova University, Adana-Turkey Project ID: 10896. We would like to thank the undergraduate thesis students for their contributions to laboratory studies 


\section{AUTHOR CONTRIBUTIONS}

V. designed project administration, funding acquisition; I.V and S.O. did sample collection, conceptualization, methodology, writing, investigation, reviewing, editing; A.T., S.Y., B.H., O.U. Performed laboratory analysis, A.S. assist for sample collection.

\section{FUNDING}

This study was supported by Çukurova University, Adana-Turkey Project ID: 10896. We would like to thank the undergraduate thesis students for their contributions to laboratory studies.

\section{CONFLICTS OF INTEREST}

The authors declare that this work has not been published previously and there are no conflicts of interest. The authors declare no conflicts of interest.

\section{REFERENCES}

[1] WHO (World Health Organization 2016). Infant and Young Child Feeding, [Online] Available: https://www.who.int/news-room/factsheets/detail/infant-and-young-child-feeding.

[2] A. Arsalan, S.B.S. Naqvi, S.I. Ali, and Z. Anwar, "Contamination of microorganisms in pediatric Infant formulae marketed in Karachi," Annals. Food Sci. Technol., vol 14, no.2, pp. 319-326, January 2013.

[3] S. Fanning, and S.J. Forsythe, Isolation and identification of Enterobacter sakazakii. In: Enterobacter sakazakii,” Ed By: Jeffrey M. Farber and Stephen J. Forsythe. ASM Press, Washington, 2008, pp. 27-59.

[4] J. Cappozzo, L. Jackson, H.J. Lee, W. Zhou, F. Al-Taher, et al., "Occurrence of ochratoxin A in infant foods in the United States," $J$. Food Prot., vol 80, pp. 251-256, doi: 10.4315/0362-028X.JFP-16339, February 2017.

[5] B. Kabak, "Ochratoxin A in cereal-derived products in Turkey: Occurrence and exposure assessment," Food Chem. Toxicol., vol. 47, no. 2, pp. 348-52, December 2009. doi: 10.1016/j.fct.2008.11.019.

[6] CXS (Codex Alimentarius International Food Standards 2006). Standard for Processed Cereal-Based Foods for Infants and Young Children, CXS 74-1981 Revised in 2006, [Online] Available: http://www.fao.org/fao-who-codexalimentarius/shproxy/en/?lnk=1\&url=https $\% 253 \mathrm{~A} \% 252 \mathrm{~F} \% 252 \mathrm{Fw}$ orkspace.fao.org $\%$ 252 Fsites $\% 252$ Fcodex $\% 252$ FStandards $\% 252$ FCXS\%2B741981\%252FCXS_074e.pdf.

[7] CXS (Codex Alimentarius International Food Standards 2019). 41 Session of the Codex Committee on Nutrition and Foods for Special Dietary Uses (CCNFSDU), [Online] Available: https://www.fssai.gov.in/upload/uploadfiles/files/Brief_Report_41st_ Codex_CCNFSDU_03_02_2020.pdf.

[8] EC (Commission Regulation 2005). Commission Directive No 2073/2005 on Microbiological Criteria for Foodstuffs, [Online] Available: content/EN/TXT/PDF/?uri=CELEX:02005R207320140601\& from $=\mathrm{EN}$.

[9] TFC (Turkish Food Codex 2011a). Regulation on Turkish Food Codex Microbiological Criteria, [Online] Available: https://www.tarimorman.gov.tr/Belgeler/ENG/Legislation/regulation microbiological_criteria.pdf.

[10] X. Wang, J. Meng, J. Zhang, T. Zhou, and Y. Zang, et al., "Characterization of Staphylococcus aureus isolated from powdered infant formulae milk and infant rice cereal in China," Int J Food Microbiol., vol. 153, no. 1-2, pp. 142-147, February 2012. doi:10.1016/j.ijfoodmicro.2011.10.030.

[11] E. Rahimi, F. Abdos, H. Momtaz, Z.T. Baghbadorani, and M. Jalali, "Bacillus cereus in infant foods: Prevalence study and distribution of enterotoxigenic virulence factors in Isfahan province, Iran," Hindawi Publishing Corporation Iran. Sci. World J., vol. 1, pp. 1-5, May 2013. doi:10.1155/2013/292571.

[12] J. Kadariya, T.C. Smith, and D. Thapaliya, "Staphylococcus aureus and Staphylococcal Food-Borne Disease: An Ongoing Challenge in
Public Health,” Biomed. Res. Int., vol. 4, no. 1, pp. 1-9, April 2014. doi: $10.1155 / 2014 / 827965$.

[13] C. Sezer, L. Vatansever, and N. Bilge, "The Microbiological quality of infant milk and follow-on formula," Van Vet J., vol. 26, no. 1, pp. 31-34, 2015

[14] Z.I. Sadek, M.A. Abdal-Rahman, M.S. Azab, O.M. Darwesh, and M.S. Hassan, "Microbiological evaluation of infant foods quality and molecular detection of Bacillus cereus toxins relating genes," Toxicol. Rep., vol. 5, pp. 871-877, August 2018. doi:10.1016/j.toxrep.2018.08.013.

[15] S. Ozcakmak, and A. Cetinkaya, "The presence of Cronobacter sakazakii, Enterobacteriaceae spp. and Ochratoxin-A in Infant Ricebased formula and milled rice product," HJSE., vol. 5, no. 2, pp. 8590, 2018. doi:10.17350/HJSE19030000069.

[16] G.M. Abebe, "Cronobacter sakazakii in infant food contamination and is survival strategies in hostile conditions," Int. J Pediatr. Res., vol. 6, no. 2, pp. 1-11, 2020. doi: 10.23937/2469-5769/1510067.

[17] IBFAN (International Baby Food Action Network 2018) Contaminants in baby foods. [Online] Available: https://www.ibfanicdc.org/wp-content/uploads/Product-Recall-List-2014 2019.pdf.

[18] Anonymous (2018). New Europe's Premium content: Lactalis to withdraw baby formula from 83 countries. [Online] Available: https://www.neweurope.eu/article/lactalis-withdraw-baby-formula83-countries/.

[19] IBFAN (International Baby Food Action Network 2019). Different President's Choice baby formula recalled for Cronobacter. [Online] Available: https://www.foodsafetynews.com/2019/10/differentpresidents-choice-baby-formula-recalled-for-cronobacter/.

[20] C. Iversen, and S. Forsythe, "Isolation of Enterobacter sakazakii and other Enterobacteriaceae from powdered infant formulae milk and related products," Food Microbiol., vol. 21, pp. 771-77, December 2004. doi: 10.1016/j.fm.2004.01.009.

[21] ISO/TS 22964 (International Organization for Standardization 2006). Milk and Milk Products-Detection of Enterobacter sakazakii. The Pre-standard of the Technical Specification ISO/TS22964:2006. 1st Ed., pp. 15. Prague: The Czech Standard Institute. [Online] Available: https://www.iso.org/standard/41258.html.

[22] FDA (Food and Drug Administration 1998a). Bacteriological Analytical Manual: Staphylococcus aureus, In: AOAC International, 8th Rev. Ed., Gaithersburg, MD, pp. 12.01-12.05. [Online] Available: https://www.fda.gov/food/laboratory-methods-food/bam-chapter-12staphylococcus-aureus.

[23] ISO (International Organization for Standardization 2002) 6579:2002 Microbiology of food and animal feeding stuffs-Horizontal method for the detection of Salmonella spp. [Online] Available: https://www.iso.org/obp/ui/\#iso:std:iso:6579:ed-4:v1:en.

[24] L. Piknová, A. Stefanovicov, H. Drahovska, M. Sásik, and T. Kuchta, "Detection of Salmonella in food, equivalent to ISO 6579, by a threedays polymerase chain reaction-based method," Food Control, vol. 13 , no.3, pp. 191-194, April 2002. doi: 10.1016/S09567135(01)00099-8.

[25] CDC (Centers for Disease Control and Prevention 1993). Salmonella serotype Tennessee in powdered milk products and infant formulae Canada and United States, Morbidity and Mortality Weekly Report.

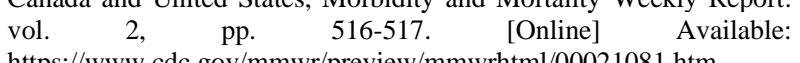
https://www.cdc.gov/mmwr/preview/mmwrhtml/00021081.htm.

[26] F. Gök, and I. Var, "Piyasadan sağlanan tahin helvalarının mikrobiyolojik kalitesinin belirlenmesi ve Salmonella spp. izolasyonu," M.S. thesis, Dept. Food Eng., Çukurova Univ., Adana, Turkey, 2005.

[27] FDA (Food and Drug Administration 1998b). Bacteriological Analytical Manual Chapter 10: Detection of Listeria monocytogenes in foods and environmental samples, and enumeration of L. monocytogenes in foods. [Online]. Available: https://www.fda.gov/food/laboratory-methods-food/bam-chapter-10detection-listeria-monocytogenes-foods-and-environmental-samplesand-enumeration.

[28] FDA (Food and Drug Administration 2002). BAM: Enumeration of Escherichia coli and the coliform bacteria. [Online] Available: https://www.fda.gov/food/laboratory-methods-food/bam-chapter-4enumeration-escherichia-coli-and-coliform-bacteria.

[29] CDC (Centers for Disease Control and Prevention 1994). Centers for Disease Control and Prevention. E. coli O157:H7: Procedure for Isolation and Identification from Stool Specimens. Foodborne and Diarrheal Diseases Branch, Division of Baterial and Mycotic Diseases, National Center for Infectious Diseases.

[30] FDA (Food and Drug Administration 1998c). Bacteriological Analytical Manual (BAM): BAM Appendix 2: Most Probable Number from serial dilutions. [Online] 
Available:https://www.fda.gov/food/laboratory-methods-food/bamappendix-2-most-probable-number-serial-dilutions\#references.

[31] A. Tekin, and I. Var, "Dondurmalardan Listeria spp'lerin izolasyonu ve tanımlaması üzerine bir araştırma," Ç.Ü. Müh. Fak. Derg., vol. 25, no. 2, pp. 153-161, 2011.

[32] FDA (Food and Drug Administration), "Bacteriological Analytical Manual (BAM): Bacillus cereus," [Online]. Available: https://www.fda.gov/food/laboratory-methods-food/bam-chapter-14bacillus-cereus, 2012.

[33] ISO 7932:2004 (International Organization for Standardization 2004). Microbiology of food and animal feeding stuffs-Horizontal method for the enumeration of presumptive Bacillus cereus-colony count technique at 30 degrees C. [Online] Available: https://www.iso.org/standard/76664.html.

[34] AOAC (Official Methods of Analysis 2014, AOAC SMPR® 2014.016). Standard Method Performance Requirements (SMPRs $\left.{ }^{\circledR}\right)$ 2014.016: Revised: Determination of Fluoride in Infant and Adult/Pediatric Nutritional Formula Approved by AOAC Stakeholder Panel on Infant Formula and Adult Nutritionals (SPIFAN). [Online] Available:

http://www.eoma.aoac.org/SMPR/upload/45/SMPR\%202014_016.pd f.

[35] M. Gökmen, K.K. Tekinşen, and U. Gurbuz, "Presence of Enterobacter sakazakii in milk powder, whey powder and white cheese produced in Konya," Kafkas Üniv.Vet Fak. Derg, vol.16 (Suppl-A), pp. 163-166, January 2010. doi:10.9775/kvfd. 2010.2801.

[36] M.K. Jung, and J.H. Park, "Prevalence and thermal stability of Enterobacter sakazakii from unprocessed ready-to-eat agricultural products and powdered infant formulae," Food Sci. Biotechnol., vol. 15, no. 1, pp. 152-157, 2006. 2092-6456 (eISSN).

[37] M.C. Pina-Pérez, D. Rodrigo, and A. Martínez, "Non-thermal inactivation of Cronobacter sakazakii in infant formula Milk: A Review, Crit. Rev. Food Sci. Nutr., vol. 56, no. 10, July 2015. doi: 10.1080/10408398.2013.781991.

[38] G. Boué, E. Cummins, S. Guillou, J.P Antignac, B.L. Bizec, and J.M. Membré, "Public health risks and benefits associated with breast milk and infant formula consumption," Crit. Rev. Food Sci. Nutr. Vol. 58, no. $1, \quad$ pp. 126-145, January 2016. doi: 10.1080/10408398.2016.1138101.

[39] T.M. Osaili, R.R. Shaker, M.M. Ayyash, A.A. Al-Nabulsi, S.J. Forsythe, "Survival and growth of Cronobacter species (Enterobacter sakazakii) in wheat-based infant follow on formulae. Lett. Appl. Microbiol., vol. 48, no. 4, pp. 408-412, March 2015. doi:10.1111/j.1472-765X.2008.02541.x.

[40] FAO and WHO (World Health Organization-Food and Agriculture Organization 2006), "Enterobacter sakazakii and Salmonella in powdered infant formulae; meeting report. Microbiological risk assessment series 10," WHO press, Geneva, Switzerland. [Online] Available: http://www.who.int/foodsafety/publications/ micro/mra10/en/

[41] F.J. Angulo, S.M. Cahill, I.K. Wachsmuth, M. de Lourdes Costarrica, and P.K.B. Embarek, "Powdered infant formulae as a source of Salmonella infection in infants," Clin. Infect. Dis., vol. 46, no. 2, pp. 268-273, January 2008. doi: 10.1086/524737.

[42] S.A. Kim, S.W. Oh, Y.M. Lee, J.Y. Imm, and I.G. Hwang, et al, "Microbial contamination of food products consumed by infants and babies in Korea," Lett. Appl. Microbiol., vol. 53, no. 5, pp. 532-538, November 2004. doi: 10.1128/CMR.17.3.638-680.2004.

[43] D. Kaufman, and K.D. Fairchild, "Clinical microbiology of bacterial and fungal sepsis in very-low-birth weight infants," Clin. Microbiol. Rev., vol. 17 , no. 3, pp. 638-680, July 2004. doi: 10.1128/CMR.17.3.638-680.2004.

[44] FAO and WHO (Food and Agriculture Organization and World Health Organization 2004), "Enterobacter sakazakii and other microorganisms in powdered infant formulae," Microbiological Risk Assessment series no. 6. [Online] Available: http://www.fao.org/3/y5502e/y5502e0c.htm\#bm12.1.

[45] FAO and WHO. (Food and Agriculture Organization and World Health Organization 2008). Report of the 2nd Session of the Codex Committee on Contaminants in Foods. The Hague, The Netherlands, 31 March-4 April 2008. Rome, Food and Agriculture Organization of the United Nations, Joint FAO/WHO Food Standards Programme, Codex Alimentarius Commission. [Online] Available: http:// www.codexalimentarius.net/download/report/700/al31_41e.pdf.

[46] Z.W. Jaradat, W. Al Mousa, A. Elbetieha, A.A. Nabulsi, B.D. Tall, "Cronobacter spp.-opportunistic food-borne pathogens. A review of the irvirulence and environmental-adaptive traits," J Med. Microbiol. 63, 1023-1037, May 2014. https://doi.org/10.1099/jmm.0.073742-0.

[47] T. Roberts, A. Ahl, and R. McDowell, "Risk assessment for foodborne microbial hazards. Tracking foodborne pathogens from farm to table," Data Needs to Evaluate Control Options," T. Roberts, H. Jensen, and L. Unnevehr, eds., U.S. Department of Agriculture, Economic Research Service, MP-1532, pp. 95-115, January 1995 [Online] http://www.ers.usda.gov/publications/MP1532/mp1532.pdf.

[48] A. Unluturk, and F. Turantaş, "Gıda Mikrobiyolojisi," 3. Baskı. sayfa 77-81. Ege Üniversitesi Ege Meslek Yüksekokulu Gıda Teknolojisi Programı, İzmir, Türkiye, 2003.

[49] S. Fanning, and S.J. Forsythe (2008). Isolation and identification of Enterobacter sakazakii. In: Enterobacter sakazakii, Ed By: Jeffrey M. Farber and Stephen J. Forsythe. ASM Press, Washington, pp. 27-59.

[50] E.Threlfall, L. Ward, M. Hampton, A.M. Ridley, B. Rowe, et al. "Molecular finger printing defines a strain of Salmonella enterica serotype Anatum responsible for an international out break associated with formulae-dried milk," Epidemiol. Infect., vol. 121, no. 2, pp. 289-293, October 1998. doi:10.1017/s0950268898001149.

[51] J. Park, Seok, W., Choi, B., H.M. Kim, B.K. Lim, et al, “Salmonella enterica sero var. London infections associated with consumption of infant formulae," Yonsei Medical Journal, vol. 45, no.1, pp. 43-48, February 2004. doi:10.3349/ymj.2004.45.1.43.

[52] J.B. Gurtler, J.L. Kornacki, and L.R. Beuchat, "Enterobacter sakazakii: A coliform of increased concern to infant health," Int $J$ Food Microbiol., vol 104, no. 1, pp.1-34, 2005. doi:10.1016/j.ijfoodmicro.2005.02.013.

[53] S. Estuningsih, C. Kress, A.A. Hassan, O. Akineden, E. Schneider, and E. Usleber, "Enterobacteriaceae in dehydrated powdered infant formulae manufactured in Indonesia and Malaysia. $J$ Food Protect., vol. 69, no. 12, pp. 3013-7, December 2006. Doi:10.4315/0362-028x-69.12.3013.

[54] K. Oonaka, K. Furuhata, M. Hara, and M. Fukuyama, "Powder infant formulae milk contaminated with Enterobacter sakazakii," Jpn J Infect. Dis., vol. 63, no. 2, pp. 103-7, March 2010. PMID: 20332571

[55] L. Yan, Q. Feng, S. Mei-Iing, Wei, W., "Screening for Enterobacteriaceae bacteria in infant formulae powder," J Northeast Agric. Univ. (English edition), vol. 19, no. 1, pp. 68-72, March 2012. doi: 10.1016/S1006-8104(12)60041-5.

[56] CAC (Codex Alimentarius Commission 2008). Code of Hygienic Practice for Powdered Formulae for Infants and Young Children (CAC/RCP66-2008). Rome: Joint FAO/WHO Food Standards $\begin{array}{lll}\text { Programme. } & \text { [Online]. }\end{array}$ https://www.maff.go.jp/j/shokusan/seizo/pdf/66-2008.pdf.

[57] J. Chap, P. Jackson, R. Siqueira, N. Gaspar, C. Quintas, et al., "International survey of Cronobacter sakazakii and other Cronobacter spp. in follow-on formulae and infant foods," Int. J Food Microbiol., vol. 136, no. 2, pp. 185-188, December 2009. doi:10.1016/j.ijfoodmicro.2009.08.005.

[58] T. Tuncer, U. Çiftçi, and M. Aydın, "Çocuk mamalarında Bacillus cereus araştırmas1," Türk Hij. Den. Biyol. Derg., vol. 44, no.1, pp.2735. 1987.

[59] Ö. Ergün, H. Aksu, Ö.Ö. Arun, and Çolak, H., "Ülkemizde satılan bebek ve çocuk mamalarında gıda zehirlenmesine neden olan önemli bazı mikroorganizmaların varlığı üzerine araştırmalar," Glda. Vol. 27, pp. 253-57, 2002.

[60] M. Shadlia Matug, K.E. Aidoo, A.A. Candlish, and Elgerbi, A.M., "Evaluation of some antibiotics against pathogenic bacteria isolated from infant foods in North Africa," The Open Food Sci J., vol. 2, pp. 95-101, 2008. doi: 10.2174/1874256400802010095.

[61] B.G. Çöl, "Çeşitli gidalarda Bacillus cereus toksinlerinin varlığı ve tiplendirilmesi," İstanbul Univ., Sağlık Blm. Enst., Doktora Tezi, 147, İstanbul.

[62] EC (European Commission 2006). Directive 2006/125/EC of 5 December 2006 on processed cereal-based foods and baby foods for infants and young children. [Online] Available: https://eurlex.europa.eu/legalcontent/EN/TXT/PDF/?uri=CELEX:320 06L0125\&from=EN,

[63] TFC (Turkish Food Codex 2011b). Regulation on Contaminants in foodstuffs. [Online] https://www.informea.org/en/legislation/turkish-food-codexregulation-contaminants-foodstuffs.

[64] G.A. Lombaert, P. Pellaers, V. Roscoe, M. Mankotia, R. Neil,et al., "Mycotoxins in infant cereal foods from the Canadian retail market," Food Addit. Contam., vol. 20, pp. 494-504, November 2003. doi.org/10.1080/0265203031000094645.

[65] J. Wolff, "Ochratoxin A in cereals and cereal products," Archivfür Lebensmittelhygiene, vol. 51, no. 4/5, pp. 85-88, 2000. ISSN: 0003925X, Record Number: 20003024230. Publisher: Verlag M \& Schaper H.

[66] B. Beretta, R. De Domenico, A. Gaiaschi, C. Ballabio, C.L. Galli, et al., "Ochratoxin A in cereal-based baby foods: Occurrence and safety 
evaluation," Food Addit. Contam., vol. 19, no. 1, pp. 70-75, January 2002. doi:10.1080/02652030110070021.

[67] F.S. Ferre, "Worldwide occurrence of mycotoxins in rice," Food Control, vol. 62, pp. 291-8, February 2016, doi:10.1016/j.foodcont.2015.10.051.

[68] X.D. Sun, P. Su, and H. Shan, "Mycotoxin contamination of rice in China," J Food Sci., vol. 82, no. 3, pp. 573-584, 2017. do:10.1111/1750-3841.13631.

[69] IARC (International Agency for Research on Cancer), "Monographs on the evaluation of carcinogenic risks of chemicals to humans: some food additives, feed additives and naturally occurring substances," Lyon, France. 31, pp. 191-206. [Online]. Available: https://publications.iarc.fr/Book-And-Report-Series/Iarc-

Monographs-On-The-Identification-Of-Carcinogenic-Hazards-ToHumans/Some-Food-Additives-Feed-Additives-And-NaturallyOccurring-Substances-1983, 1983.

[70] J. L. Herrman, and R. Walker (1999). Risk analysis of mycotoxins by the Joint FAO/WHO Expert Committee on Food Additives (JEFCA), FNA/ANA 23: 17-24. [Online] Available: http://www.fao.org/3/X2100t/X2100t06.pdf.

[71] A. Goncalves, A. Gkrillas, J.L. Dorne, C. Dall'Asta, R. Palumbo, et al., "Pre- and postharvest strategies to minimize mycotoxin contamination in the rice food chain," Compr Rev Food Sci. Food. vol. 18, pp. 441-454, February 2019. doi:10.1111/1541-4337.12420.

[72] T. Baydar, P. Erkekoğlu, H. Sipahi, G. Sahin, "Aflatoxin B1, M1 and Ochratoxin A levels in infant formulae and baby foods marketed in Ankara, Turkey," J Food Drug Anal., vol. 15, no. 1, pp. 89-92, March 2007. doi:10.38212/2224-6614.2446.

[73] E.A. Johnson, W.H. Tepp, M. Bradshaw, R.J. Gilbert, P.E. Cook, et al., "Characterization of Clostridium botulinum strains associated with an infant botulism case in the United Kingdom," $J$ Clin Microbiol., vol. 43, no. 6, pp. 2602-7, June 2005. doi: 10.1128/JCM.43.6.2602-2607.2005.

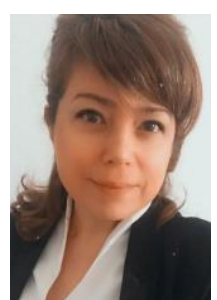

Ozcakmak S. She recived her Master's Degree and $\mathrm{PhD}$ on Food Microbiology from Trakya University. Her studies focused on Food Microbiology, Natural Antimicrobial Agents, Food Management Systems and Food Law. She worked as an academic staff in a university from 1999 to 2013 years. She has many 'Oral and Poster Presentations' in National and International Scientific Conferences. She has published articles in SCI, SCI-Expanded, National and other indexed Journals. She was carried out scientific, social and educational projects in cooperation with the other organizations from 2006 to 2019. She has been working as an "Official Food Audit and Inspection" in Directorate of Provincial Agriculture and Foresty since 2013. She published a book with its $2^{\text {nd }}$ printed which is titled "Food Safety within the content of legislation" edited by Var I.

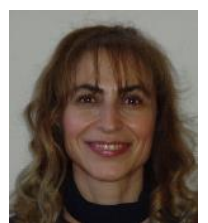

Var I. is a professor at the Department of Food Engineering, Çukurova University, Adana, Turkey. She gives the lectures and also study about General Microbiology, Food Safety, Food Microbiology, Food Hygiene and Sanitation, Food Biotechnology, Mycotoxins, Molecular Biology.

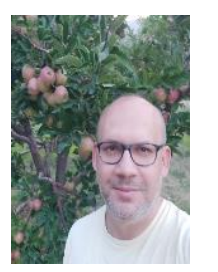

Tekin A. works as a Researcher at the General Directorate of Agricultural Research and Policies. His studies focused on Food Microbiology and Mycotoxins in agricultural products. In addition, he has recently carried out studies on bioactive components, fatty acid compositions and nutritional properties in fruit products.

Yılmaz S. is a food engineer at health and nutrition science department of SGS Group. Working on food microbiology, Y1lmaz S., continues her master's degree in Cukurova University, Department of Food Engineering.

Hesmati B. was graduated from the Department of Cell and Molecular Biology at Bonab University in Iran in 2010. He completed his doctorate in Çukurova University, Department of Biotechnology in 2019. His research interests also include the food microbiology and food hygiene and sanitation.

Uçkun, O. She received his master's degree on "Determination of aroma and aroma active compounds of citrus and geven honeys". Later started working on mycotoxins and she has finished her PhD in 2021 which the subject of "The Effect of Different Extraction Methods on Total Aflatoxin in Peanut and Sunflower Oil Processing and Investigation of the Change in Aflatoxin During the Process". She worked as a food engineer at the Ardanuc District Directorate of Food, Agriculture and Livestock/Artvin, Oil Seeds Research Station Directorate/Osmaniye, and She most recently works as a food engineer in the contaminants laboratory of Adana Food Control Laboratory Directorate.

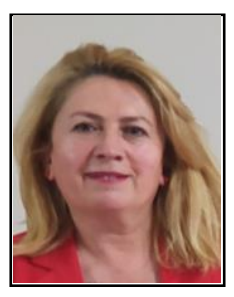

Çetinkaya A. is an asistant professor at the Department of Food Engineering, Kafkas University, Kars, Turkey. More recently, she has worked in the field of fatty acids and flavor compounds of dairy products. Her research interests also include the production and chemistry of different types of cheese, their biochemistry, lactic acid bacteria in dairy products, traditional materials in cheeses. 